\title{
ETHICAL LEADERSHIP AND TEACHER PROFESSIONAL VALUES: MATTERS ARISING FROM THE NORTHERN REGION OF GHANA
}

\author{
Robert Ampomah ${ }^{\mathrm{i}}$ \\ Akenten Appiah Menka University of \\ Skills Training and Entrepreneurial Development, \\ P. O. Box 40, Asante Mampong, \\ Ghana
}

\begin{abstract}
:
School heads as senior executives are thought to provide the institution ethical tone at the top to impact on subordinates. As a result, the study investigated how heads ethical leadership and teacher professional values influence students' academic achievement, using a survey of 370 respondents in senior high schools in the Northern Region of Ghana. Questionnaires were used to collect data and analysed using descriptive and inferential statistics. It emerged from the study that ethical leadership practice of school heads and unadulterated professional values are fundamental to teachers, students and the entire school organization. Results from the study showed that mentorship, honesty and trust were core ethical leadership attributes of heads. The current study and other empirical research points to the fact that teacher professional values including reliability, professionalism and trust are keen in teacher's career success. The study recommends that practicing and prospective heads are made to go for professional development sessions on ethical leadership behaviours. Again, induction and effective orientation on professional standards and values should form part of teacher recruitment and lifelong learning since they are vital for positive teacher identity and excellent learning outcomes.
\end{abstract}

Keywords: ethical leadership, professional values, ethics, behaviour, motivation

\section{Introduction}

\subsection{Background}

The role of school heads and teachers nowadays are becoming more and more complex, and calls for certain standards of professional practice (Hargreaves \& Goodson, 1996; Harris \& Muijs, 2005). This requires the development of a comprehensive leadership training and ethics for success. Educational leadership is noted to be a significant contributing factor of high school performance (Beck and Murphy, 1997). In our complex educational setting peopled with varied human behaviour, ethical leadership is

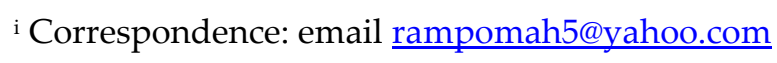


inevitable. Ethical leadership is about the implicit and explicit pursuit of desired behavior for self and ones followers through efforts governed by rules and principles that advocate learning motivation, healthy optimism and clarity of purpose to uphold the values of empowerment, service to others, concern for human rights, change for betterment and fulfilling duties towards society, future generations, environment and its sustainability, (Shakeel et al., 2018). Being ethical as a professional teacher and a leader is to demonstrate conduct for the common good that is acceptable and appropriate in every area of life. Academic success is not only dependent on ethical leadership of the school head but also accrue professional values demonstrated by teachers. Whitaker (2003) posits that an effective leader's essential ethical values include what is best for students and expectations of the faculty and staff. Hence, Bass (1999) describes that leaders should be selflessly committed to organizational success through maintaining these core values. From education perspective, research on ethical leadership is needed to guide current selection, training, development, reward and retention practices (Ramakrishna \& Potosky, 2003). Ghana's quest to achieving the United Nations Sustainable Development Goals on Education goal four, which proposes that, by 2030, "all girls and boys should complete free, equitable and quality primary and secondary education" require that we pay critical attention to leadership in school and teacher professional values to minimise abuse of power by leadership and teachers with its attendant repercussions in school.

\section{Problem Statement}

Ethical leadership and teacher professional values within the Ghanaian context are not new concepts. Leadership in all spheres of human endeavour plays an important role in social structure of most communities (Sikua, 2002). The general consensus on school leadership studies is that successful schools have good leaders (Spillane et al, 2004). Therefore, ethical leadership can certainly contribute to school improvement by ensuring the motivation, participation and coordination of the teachers (Goldhaber, 2002).

What has generated much debate about ethical leadership of school heads and teacher professional values on students' academic success in the Northern region is the persistent call for heads of educational institutions and teachers in particular to do more to step up performance of students in the wake poor academic achievements. In the light of the above, this study attempts to find out how ethical leadership of school heads and professional values possessed by teachers impact students' academic success in senior high schools in the study area.

\subsection{Specific Objectives}

1) To identify ethical leadership attributes of senior high school heads in the northern region.

2) To identify professional values possessed by teachers in senior high schools in northern region. 
3) To determine the influence of ethical leadership on students' academic achievements.

\subsection{Research Questions and Hypothesis}

The following research questions and hypothesis were formulated to guide the study:

1) Which ethical leadership attributes are dominant among SHS heads in the northern region?

2) Which teacher professional values are demonstrated in SHS in the northern region?

\subsection{Hypothesis}

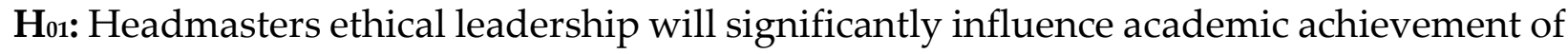
students in northern region senior high schools.

\subsection{Theoretical Framework of Ethical Leadership}

Ethical leadership is governed by self-regulation, justice, care and critique, Starratt (1991). Ethical leadership is "the demonstration of normatively appropriate conduct through personal actions and interpersonal relationships, and the promotion of such conduct to followers through two-way communication, reinforcement, and decision-making" (Brown, Treviño, \& Harrison, 2005, p. 120). According to Rebore (2001) there are three reasons why ethics thinking is so crucial to educational leadership. The first is that the concerns of ethics are vital for decision-making and the necessary deliberation upon central morals. The second reason is that an ethical attitude is a well-ordered attitude. Thirdly, ethical study provides an exceptional plan. Sergiovanni (2005) posits that "Leadership is a responsibility. Leaders minister to the needs of the school by being of service and providing help to every member of the school environment. Leadership combines management know-how with values and ethics"' (p. 19). Barth (2001) describes that students benefit in such an environment because they notice and emulate democratic beliefs which can result in their improved achievement in all spheres of school life.

Studies on ethical leadership have an increasing relevancy to organizational practice (Hsin-Kuang, Chun-Hsiung \& Dorjgotov, 2012). Neubert, Wu, \& Roberts (2013) argue that the collapse of organizations is as a result of lack of ethical behaviour. When the school lacks leadership that fails to deal with teachers, students and other employees in a manner that will promote ethics, it is likely to cause harm to the morale of employees, thus invoking the need for regulation on the basis of ethical leadership. According to Rehman (2011), it is evident that the competitive nature of business in the global market place has shaped the trajectory whereby the expansion of ethical behaviour has been exponential. As a result, the widening scope of ethical concerns in the contemporary businesses is a greatest pointer to the needs of ethical leadership (Ung Hee, Hye Kyoung, \& Young Hyung, 2013). A study by Caldwell, et al., (2012) shows that the significant issue that challenges modern organizations is the reduced application of ethical behaviour. Such realization informs that the principles of ethical behaviour are widely non-existent 
thereby drawing the definition that trust among leadership leads to increased motivation among employees and this becomes reflected in the productivity and performance of the organization. In view of this, without ethical leadership, the shadow side of leadership is strengthened thus increasing the tendency to negatively influence privileges, powers, inconsistency, deception, misplaced loyalties and irresponsibility (Giessner \& Quaquebeke, 2010). It follows that employees become exposed to negative influences and generally become affected by losing trust as well as integrity in their leader.

Some of the elements of ethical leadership which affects education are caring; supporting staff; building confidence in others; establishing high standards of performance; motivating stakeholders; communicating effectively; problem-solving; lifting and maintaining high morale; inspiring faculty, staff and students to do their best and modeling expectations (Bass, 1999; Day et al., 2001; Hawthorne, 2001; Paul, 1988; Rice \& Dreilinger, 1990). The teaching profession has code of conduct and the power and machinery to enforce ethical conduct of teachers. Hence, Beck and Murphy (1997) view ethical leadership as a two-step process. First, it is necessary that leaders view ethics as a set of fundamental principles that guide their decision making process. Applying ethical principles to daily decision making helps the leader the opportunity to make decisions that are ethically sound (Furman, 2003). Second, they contend that leaders must embrace ethics as a necessary element of character. Accordingly, ethics is less about making decisions using objective principles and more about living morally in specific situations. Davis (1998) points out that good decision-making in leadership is guided in obligations that are embedded in shared values, trust, honesty, fairness, equity, empowerment, human dignity, doing the right thing, rule of law and beneficence, which are referred to as central ethics that guide the entire organization in the face of stringent demands. These ethics are also requirements for building what Sergiovanni (1992) calls a virtuous school that strives to meet every need of students. Capper (1993) advances the idea of a virtuous school by stating, "Administrators can practice this ethic of caring through all their interpersonal interactions and in building a nurturing school culture that consistently demonstrates what the people in the school care about" (p. 273). In ethical leadership, Sergiovanni (2005) suggests that school leaders ask themselves, the kind of values and believe that should guide actions.

It is crucial that ethical leadership must be grounded on a central core of principles that are unshaken by dilemmas and other position-related difficulties. Mayeroff (1971) describes some principles: commitment, understanding, forbearance, integrity, faith in others, meekness and student-centeredness. Without these core principles, leadership is impossible to succeed. In the words of Beck (1994) understanding others' trains of thought, responding appropriately to others and staying committed to the relationship. Beck believes that these principles support growth and helps take care of the needs of others, as the author notes, "Actions and attitudes consistent with caring are linked to observable positive outcomes in societies, organizations, and persons" (p. 38). Starratt (1994, cited in Marshall and Oliva, 2006) stressed the idea that one of the focal ethical duties of education leaders is to ensure that all non-dominant cultural groups are treated 
respectfully. Growe, Fontenot, and Montgomery (2003) posit "Principals have to serve the students not only as a principal, but also as a parent and counselor in some instances" (p. 19). Sergiovanni (2005) further offers the principles, virtues, of optimism, credibility, camaraderie and respect for diversity as necessary in ethical leadership.

\subsection{Implications of Ethical Leadership on Education}

Educational leaders are to ensure that organizational values that are suitable for the survival of the institution are maintained. Hence, Rebore (2001) states "The principal can have the most extensive impact on a school's culture" (p. 62) because of positional authority. Thus, the influence of an effective educational leader on school's life are quite exemplary. Alvy and Robbins (1998) describe that if affiliations within the school are strong, the moral impact of education leaders' decisions and actions elevates behaviour in the school. However, Weissbourd (2003) believes that it is not just important to set an example for others, but the level of commitment of leaders' relationships with students is just as important. In the words of Lambert et al. (2002), "School leaders must search for ways to create a culture of high expectations and support for all students and a set of norms around teacher growth that enable teachers to teach all students well" (p. 3). This statement points to the fact that a well-positioned educational leader who arms him or herself with the basic ethics in leadership will surely succeed and impact positively on the learner.

Blase and Blase (2000, cited in Barnett, 2004) note that when education leaders maintain channels of communication and opportunities for improvement with faculty and staff, they more positively influence students' achievement. One tool for influencing students' achievement is professional development instituted by the education leader to promote successful instructional practice. Dewey (1944) discussed that schooling is unique because "adults consciously control the kind of education which the immature get by controlling the environment in which they act, and hence think and feel" (pp. 18-19) in order to improve society. Therefore, inability on the part of school leaders to develop ethical competence constitutes a failure to serve the children they are obliged to serve. As a profession, educational leaders thus have a moral obligation to train teachers as well as students to be able to apply the principles, rules, ideals and virtues associated with the development of ethical schools, Shapiro \& Stefkovich (2005). Avey et al., (2009) observed a positive relationship between ethical leadership and employees' psychological ownership of the work they do.

\subsection{Teacher Professional Values}

Professional values of teachers measure all the characteristics of teaching profession like responsibilities, attitude, fairness, integrity, loyalty, justice, faithfulness, respect for others, self- teaching procedures and assessment of students. Blankstein (2004) states that "Ideally, values reflect the attitudes and beliefs of the school community" (p. 85). A typical professional value of a teacher according to Sergiovanni (1992) is that the teacher must be a role model of the school community's values. This means that the teacher must set good example for staff and students to emulate. According to Little (1999, cited in 
Lashway, 2001), "school values, beliefs and norms must support teacher learning" (p. 2). Shapiro and Gross (2002) show that student teachers in their study developed their own personal values, codes for being professional and that these become the basis for the practices they decide they could live with, defend and justify. The tasks of teachers nowadays are becoming more and more complex, which need a high standard of professionalism and values in order to be a truly effective teacher. Mahat (2009), therefore states that teachers are not only to teach; they need to prepare and to be practical in preparing themselves to educate the students. The values that need to be upheld by teachers comprised of self (personal)-values, professionalism values and social values. Teachers are expected not to only focus on the classroom itself, but to teach good manners to the students in order to fulfill the national education philosophy which demands holistic types of students as the final product of the education process, Md Sawari \& Mustaffa, (2014). Teachers can create classroom environment that is effective to ensure that students are always interested and feeling fun to learn. This can only be done by teacher leaders who are concerned with the students' needs in the classroom. Begley (2004) is of the view that dialogue is an essential but often forgotten component that foster understanding, acquisition and adherence to values of the teaching profession in learning communities. The necessity of dialogue for perspective-taking, negotiation and realisation of professional values was later reinforced by Sunley \& Locke (2012). A teacher with professional values creates a conducive classroom environment influenced by physical, social and emotional factors. To achieve this, the teacher must have a positive attitude and high expectation towards students' personality (Gani Hamzah, Basri \& Daud, 2010). Teachers must be able to provide the best illustrations. A good teacher must be able to transform a student to become a person of value, (Mohammed Shatar, Azali \& Jasni, 2006). A teacher should have a personal or self-values in order to be a good and effective practitioner in the mission to fulfill the national education aims and to produce a generation that has values, character, discipline, morality, identity and competence.

Teachers can create classroom culture that is effective to ensure that students are always interested and feeling fun to learn. A teacher with values should have a strong faith in God and also have a firm belief in religion (Saeeda, 2006).

A teacher should have acquired personal or self-values in order to be a good and effective leader in the mission to fulfill the national education's aim to produce a generation which has value, character, discipline, morality, identity and competence. Teachers are expected to have excelled nature and character, and education in conveying knowledge. Demonstrating these values will make you succeed in your career. However, there are some teachers who still go against the teaching values and standard and as a result fail to understand the ethics and manners that are required (Baharin \& Suzana, 2010). 


\section{Methodology}

\subsection{Research Design}

The design used for the study was the quantitative survey design. Survey is commonly applied to a research design aimed to collect data from a specific population, or a sample from that population, and typically utilizes questionnaire or an interview as the survey instrument (Cohen. Manion \& Morrison, 2007). Survey designs are used to obtain data from individuals about themselves, their households, or about larger social institutions. This design is therefore appropriate for this study because it seeks to collect data from a sample of professional headmasters and teachers in senior high schools on ethical leadership and teacher professional values using questionnaires.

\subsection{Population}

The population for the study consisted of all headmasters, assistant headmasters and teachers in Senior High Schools in the Northern Region of Ghana. The number of headmasters, assistant headmasters and teachers used for the study does not dispute the adequacy of the sample used and it is in accordance with Tabacknick and Fidell (2012) sample size adequacy determination formula.

\subsection{Sample and Sampling Procedure}

A sample of 370 staff members comprising headmasters, their assistants and teachers were selected from the Senior High Schools, consisting of 241(65.17\%) males and 129 $(34.9 \%)$ females. The ages of the respondents range from 26 to 59 years with an average age of 37.4 years. The respondents were selected through the purposive and convenience sampling technique respectively. The headmasters were purposively selected whilst teachers who were at post during data collection period were contacted to respond to the questionnaire.

\subsection{Instruments for Data Collection}

The study adapted ethical leadership scale questionnaire by Brown et al., (2005) and the Korthagen et al. (2002) values questionnaire. These instruments aim at facilitating reflection on various professional ethics and values and how they relate to teachers in an educational institutions. These questionnaires were revised to a four point scale ranging from strongly agree to strongly disagree. Based on the items or variables indicated on heads ethical leadership and teacher professional values.

\subsection{Data Collection}

In each school the researcher contacted the headmaster first and obtained permission to collect data on the study. Teachers in the schools who the researcher chanced upon were also contacted. After which the questionnaires were distributed to them. The rationale for the study was explained to the respondents without revealing the study hypotheses. The completed questionnaires were collected within one week after distribution. 


\subsection{Data Analysis}

Descriptive statistics (mean scores and standard deviations) and inferential statistics (One Way ANOVA) were employed to analyse the data, and the results presented in Tables.

\section{Results and Discussion}

This section presents and discusses the results of the study in an attempt to answer the research questions and hypothesis.

\subsection{Results}

Research Question 1: Which ethical leadership attributes are dominant among SHS heads in the Northern Region?

Table 1: Ethical leadership attributes among SHS heads

\begin{tabular}{|l|c|c|c|c|}
\hline Ethical leadership attributes & $\mathbf{N}$ & Mean & Std.D & Variance \\
\hline Mentorship & 370 & 4.0144 & 1.1169 & 1.322 \\
\hline Honesty & 370 & 3.8272 & 1.2268 & 1.549 \\
\hline Supervision & 370 & 3.7669 & 1.3825 & 1.457 \\
\hline Trust & 370 & 3.7588 & 1.2348 & 1.532 \\
\hline Justice & 370 & 4.0127 & 1.49456 & 1.911 \\
\hline Overall & & 4.02528 & 1.218928 & 1.5101 \\
\hline
\end{tabular}

In measuring the ethical leadership attributes among SHS Heads, five (5) attributes were identified, and the respondents were asked to show their level of agreement or disagreement with each outcome. The results suggest that respondents agreed with each attribute identified. This was because the overall impact means score was (4.0253) and a standard deviation of (1.2189). The leading ethical leadership attributes among SHS heads mentorship, honesty, supervision, and trust as shown in Table 1. The findings of the study were supported by (Mason, \& Bailey, 2007) who indicate that the heads mentor's assistance helps to open new doors. Headmasters' role as mentor affords teachers and other internal publics of the school new opportunities. Blackman and Fenwick (2000) report that the mentorship role of the school head is to be a servant-leader, organizational and social architect, an educator, a moral agent, a child advocate and social worker, a community activist and a crisis-negotiator. The headmaster's ethical leadership in terms educational supervision is not only sensitive but also, a very broad subject. The finding corroborates with Ankoma-Sey \& Maina, (2016) and Archibong (2017). For instance, Archibong asserts that supervision as an element of the administrative process is concerned with efforts to guide the day-to-day activities of the work groups by stimulating, directing and coordinating the workers and their efforts. Furthermore, the results of this study found trust as an ethical leadership attribute exhibited by the headmasters. This is true when the head was perceived as reliable and honest Tschannen-Moran, et al. (2000). 
Research Question 2: Which teacher professional values are demonstrated in Senior High Schools in the Northern Region?

Table 2: Professional values demonstrated in schools

\begin{tabular}{|l|c|c|c|c|}
\hline Professional values in school & $\mathbf{N}$ & Mean & Std.D & Variance \\
\hline Reliable & 370 & 3.8333 & 1.4195 & 1.965 \\
\hline Professional & 370 & 3.6972 & 1.4267 & 2.035 \\
\hline Friendly & 370 & 2.7321 & 1.1916 & 1.420 \\
\hline Trust & 370 & 3.7431 & 1.4724 & 2.168 \\
\hline Punctual & 370 & 3.5634 & 1.3989 & 1.918 \\
\hline Overall & & 3.857 & 1.396 & 1.455 \\
\hline
\end{tabular}

Five (5) values were identified from the literature concerning professional values demonstrated in school, and the respondents were asked to rate each element based on their level of agreement or disagreement with each value. The results indicates that respondents agreed with each factor or value identified since the elements had an overall mean score of (3.857) and a standard deviation of (1.396). Each value had a mean score which means that all the five values indeed are relevant. However, the four leading values that were demonstrated in schools were reliable, professional, trust and punctual as shown in Table 2.

It is evident from these findings that professionalism to Hilferty (2008) is a social construct in institutions. Teachers are to demonstrate this value in their professional practice. Again, the findings supported the views of Kramer et al. (1996) who argue that trust is a pertinent topic to consider when thinking about schooling because it involves a collective effort.

\subsection{Hypothesis}

Table 3: Headmasters' ethical leadership significantly influence academic achievement of students in Senior High Schools

\begin{tabular}{|l|l|c|c|c|c|c|}
\hline One Way ANOVA & & & & & & \\
\hline Dependent & Model & Sum of Square & Df & Mean Square & F & Sig. \\
\hline Academic achievement & Regression & 23.741 & 1 & 23.741 & 4.556 & $.034^{\mathrm{b}}$ \\
\hline & Residual & 697.169 & 29 & 5.455 & & \\
\hline & Total & 730.000 & 28 & & & \\
\hline
\end{tabular}

Note: Independent variable: Ethical leadership

The regression result was presented in Table 3 above and the results show that ethical leadership of headmasters contributes about $4.5 \%$, (Sig. $=0.034, \mathrm{P}<0.05)$ of the overall variation in the dependent variable, thus academic achievement. The regression model was significant, since the ANOVA p-value $(\mathrm{Sig}=0.034, \mathrm{p}<0.05)$ was far less than 0.05 alpha level as shown in Table 3.

Trevino, Brown, and Hartman (2003) found that ethical leadership is not only associated with a leader's traits (e.g., honesty, integrity and trustworthiness) and ethical 
behaviours (e.g., openness, concern, fairness and ethical decision making) but also linked to value-based management (e.g. setting ethical standards through communication and rewards). An ethical leader is viewed as an authentically moral person by his or her followers and as a moral manager who effectively influences employees (Trevino et al., 2003; Trevino, Hartman, \& Brown, 2000). Thus, ethical leaders are moral persons who manifest moral traits and behaviours in their personal lives.

Studies that have tried to explain how ethical leadership affects follower behaviour have drawn inspiration from two theories: social learning theory (Bandura \& McClelland, 1977) and social exchange theory (Blau, 1964; Homans, 1974). Social learning theory (Bandura, 1986; Bandura \& McClelland, 1977) is used by leadership researchers to describe how ethical leaders act as role models, attracting followers' attention to their ethical practices and decision-making norms and thus, spreading ethical behaviour throughout the organization as followers emulate their leader.

\subsection{Summary of the Study}

Ethical leadership in school is a conceptualization of positive relationship that potentially exist on the backdrop of moral values, obligations of leaders and expectation of associated leadership factors. The interplay of these succinct factors gives an insight into the utilization of ethical considerations within the framework of school leadership. This is as a result of the fact that these two individuals (headmasters and teachers) are expected to bring their experiences to bear on students' life for the later to succeed.

The results from the study suggest that ethics and values as concepts in education are important to the staff, students and the entire school organization. Again, the results from the study indicate that mentorship, honesty and trust are core among headmasters ethical leadership attributes. The study highlights leadership processes and job ethics clearly demonstrated among headmasters. In fact, this study and other empirical research point to the fact that certain teacher professional values are keen to the success of the teacher and the learner.

Finally, the study confirms that, headmasters' ethical leadership significantly affect academic achievement of students and therefore contribute significantly to students' academic success in senior high schools in the study area.

\subsection{Recommendations for Practice}

From the foregoing discussion, it is recommended that prospective and practicing heads undergo leadership training on ethical leadership behaviours considering its efficacy in school life.

It is certain that there are challenging tasks of the headmaster in the school today as characterized in a scenario where everyone thinks of personal satisfaction, the evidence of numerous unethical behaviours and scandals including selfish egoistic pattern of some staff members and students. Good teachers again, sense the importance of acquiring a wider perspective on professional values. Hence, echoing professional standards within a framework of personal values and qualities appropriate to the 
teaching profession is quite necessary, Halstead and Taylor (2000). As a result of the above, induction and effective orientation on professional standards and values should form part of teacher recruitment and lifelong learning since they are vital for positive teacher identity and excellent learning outcomes.

\subsection{Limitations of the Study}

The findings of this study must be viewed in the light of a few research drawbacks. In the first place, the sample was obtained from only senior high school heads and teachers in one region in Ghana. Again, only teachers who were accessible and agreed to participate in the study were involved. By using convenience sampling teachers in the schools that participated in the study might not be representative of all teachers and schools in the region. This might affect the generalizability of the findings. Notwithstanding this, the sample of respondents was large enough to give valid findings about the variables under study.

\section{Acknowledgement}

The researcher is indebted to all headmasters and teachers who allowed for the study to be conducted in their schools and again for sacrificing their time to respond to the items.

\section{Conflict of Interest Statement}

The author declared no conflicts of interests with respect to the research, authorship, and/or publication of this article.

\section{About the Author}

Robert Ampomah is a lecturer in educational leadership, development of education in Ghana. He is a teacher educator and examination officer (DIS) in the university. His research interests include school leadership/administration and teacher education and development. As a professional teacher, Robert Ampomah has been involved in leadership and training programmes in headteacher/teacher effectiveness at various levels of education in Ghana.

\section{References}

Alvy, H. B., \& Robbins, P. (1998). If I only knew... Success strategies for navigating the principalship. Thousand Oaks, CA: Corwin Press, Incorporated.

Ankoma-Sey, V. R., \& Maina, B. (2016). The role of effective supervision on academic performance of Senior High Schools in Ghana. Journal of Arts and Humanities, vol.5 (4), p.73.

Archibong, F. I. (2017). Instructional supervision in the administration of secondary education: A panacea for quality assurance. European Scientific Journal, vol. 8, (13), p. 61-70. 
Avey, J. B., Avolio, B. J., Crossley, C. D., \& Luthans, F. (2009). Psychological ownership: Theoretical extensions, measurement and relation to work outcomes. Journal of Organizational Behaviour, 30(2), 173-191.

Baharin, A. \& Suzana, M. (2010). Pengetahuan Etika Profesion Perguruan. Dalam Kalangan Guru.

Bandura, A. (1986). Social foundations of thought and action: A social cognitive theory. Englewood Cliffs, NJ: Prentice-Hall. [Google Scholar]

Bandura, A., \& McClelland, D. C. (1977). Social learning theory. Englewood Cliffs, NJ: Prentice-Hall. [Google Scholar]

Barnett, D. (2004). School leadership preparation programmes: Are they preparing tomorrow's leaders? Education, 125(1), 121-129.

Barth, R. S. (2001). Teacher leader. Phi Delta Kappan, 82(6), 443-449.

Bass, B. M. (1999). Two decades of research and development in transformational leadership. European Journal of Work and Organizational Psychology, 8(1), 9-32.

Beck, L. G. (1994). Reclaiming educational administration as a caring profession. New York: Teachers. College Press.

Beck, L. G., Murphy, J., \& Associates (1997). Ethics in Educational Leadership Programs: Emerging Models. Columbia, MO: The University Council for Educational Administration.

Begley, P. T. (2004). Understanding valuation processes: Exploring the linkage between motivation and action. International Studies in Educational Administration, 32(2), 417.

Blackman, M. C. \& Fenwick, L. T. (2000). The principalship: Looking for leaders in a time of change. Education Week, 19(29), 46, 68.

Blankstein, A. M. (2004). Failure is not an option: Six principles that guide student achievement in high-performing schools. Thousand Oaks, CA: Corwin Press, Incorporated.

Blau, P. M. (1964). Exchange and power in social life. New York: Wiley.

Brown, M. E., Treviño, L. K., \& Harrison, D. A. (2005). Ethical leadership: A social learning perspective for construct development and testing. Organizational Behavior and Human Decision Processes, 97, 117-134.

Caldwell, C., Dixon, R., Floyd, L., Chaudoin, J., Post, J., \& Cheokas, G. (2012). Transformative Leadership: Achieving Unparalleled Excellence. Journal of Business Ethics, 109(2), 175-187.

Capper, C. A. (1993). Educational Administration in a pluralistic society. Albany, NY: State University of New York Press.

Cohen, L., Manion, L., \& Morrison, K. (2007). Research Methods in Education (6th ed.). London and New York, NY: Routledge Falmer.

Davis, J. (1998). Young children, environmental education, and the future. Early Childhood Education Journal, 26 (2), 117-123.

Day, C, Harris, A. \& Hadfield, M. (2001). Challenging the orthodox of effective school leadership, International Journal of Leadership in Education. 4(1). 39-56. 
Dewey, J. (1944). Democracy and education: An introduction to the philosophy of education. New York: The Free Press.

Furman, G. C. (2003). Moral leadership and the ethic of community. Values and Ethics in Educational Administration, Vol. 2, No.1, 1-8.

Gani Hamzah, M.S., Basri, R. \& Mohd Daud, S., (2010). Karakter guru ilmu diagung guru disanjung. Kuala Lumpur: Utusan Publications \& Distributors Sdn. Bhd. Retrieved from http://eprints.utm.my/10740/1/

Goldhaber, D. (2002). The Mystery of Good Teaching. Education Next, Spring.

Giessner, S., \& Quaquebeke, N. (2010). Using a Relational Models Perspective to Understand Normatively Appropriate Conduct in Ethical Leadership. Journal of Business Ethics, 9543-9555.

Growe, R., Fontenot, C., \& Montgomery, P. S. (2003). Tomorrow's leaders: Who are they and how will they lead? (ERIC Document Reproduction Service No. ED482265)

Halstead, M. J. and Taylor, M. J. (2000). Learning and Teaching about Values: A Review of Recent Research, Cambridge Journal of Education, 3 (2), 169-202.

Harris, A., \& Muijs, D. (2005). Improving Schools Through Teacher leadership, Maidenhead: Open University Press.

Hargreaves, A., \& Goodson, I. F. (1996). Teachers' professional lives: Aspirations and actualities. In I. F. Goodson, \& A. Hargreaves (Eds.), Teachers professional lives (pp. 1-27). London: Farmer Press.

Hawthorne, M. D. (2001). Learning by doing: Teaching decision making through building a code of ethics. Technical Communication Quarterly, 10(3), 341-355.

Hilferty, F. (2008). Teacher professionalism and cultural diversity: Skills, knowledge and values for a changing Australia. The Australian Educational Researcher, 35(3), 53-70.

Homans, G. C. (1974). Social behavior: Its elementary forms. New York, NY: Harcourt Brace Hsin-Kuang, C., Chun-Hsiung, L., \& Dorjgotov, B. (2012). The Moderating Effect of Transformational Leadership on Knowledge Management and Organizational Effectiveness. Social Behavior \& Personality: An International Journal, 40(6), 10151024.

Kramer, R. M., Brewer, M. B., \& Hanna, B. A. (1996). Collective trust and collective action: The decision to trust as a social decision. In R. M. Kramer, \& T. R. Tyler, 129 (Eds), Trust in Organizations: Frontiers of Theory and Research (pp.357-389). Thousand Oaks, CA: Sage.

Korthagen, F. A. J. (2002). De professionalisering van lerarenopleiders in Nederland. EPSReeks, 13. Utrecht: EPS.

Lambert, L., Walker, D., Zimmerman, D. P., Cooper, J. E., Lambert, M. D., Gardner, M. E., \& Szabo, M. (2002). The constructivist leader (2nd ed.). New York: Teachers College Press.

Lashway, L. (2001). Leadership for accountability. Research Roundup, 17(3), 1-4.

Mahat, M. A. (2009). Guru pendidik, pengajar atau pendakwah. Shah Alam: Karisma Publications. 
Md Sawari, S. S. \& Mustaffa, A. (2014). Guru bersahsiah mulia menurut pandangan Ibnu Shahnun: Analisa buku adab Al Mualimin. Journal of Islamic Education, 2(2), 1-10.

Marshall, C., \& Oliva, M. (2006). Leadership for social justice: Making revolutions in education. Boston: Pearson Education, Incorporated.

Mason, C., \& Bailey, E. (2007) Benefits and pitfalls of mentoring. Retrieved from http://www.faculty.english.ttu.edu/barke

Mayeroff, M. (1971). On caring. New York: Harper Collins Publishers.

Mohammad Shatar, Jasni Sabri, \& Azali Mohamed. (2006). Tip Pendidik Cemerlang. Selangor: Utusan Publications \& Distributors Sdn. Bhd.

Neubert, M., Wu, C., \& Roberts, J. (2013). The Influence of Ethical Leadership and Regulatory Focus on Employee Outcomes. Business Ethics Quarterly, 23(2), 269-296.

Paul, R. W. (1988). Ethics without indoctrination. Educational Leadership, 45(8), 10-19.

Ramakrishna, V. H. \& Potosky, D. (2003). Conceptualization and exploration of composite career anchors: An analysis of information systems personnel. Human Resource Development Quarterly 14(2):199 - 214.

Rehman, R. (2011). Role of Emotional Intelligence on the Relationship among Leadership Styles, Decision Making Styles and Organizational Performance: A Review. Interdisciplinary. Journal of Contemporary Research in Business, 3(1), 409-416.

Rebore, R. W. (2001). The ethics of educational leadership. Upper Saddle River, NJ: PrenticeHall, Incorporated.

Rice, D. \& Dreilinger, C. (1990). Rights and wrongs of ethics training. Training and Development Journal. 44(5). 103-108.

Saeeda, J. A Shah. (2006). Educational leadership: An Islamic perspective. British Educational Research Journal 32(3):363-385.

Sergiovanni, T. J. (1992). Moral leadership: Getting to the heart of school improvement. San Francisco: Jossey-Bass.

Sergiovanni, T. J. (2005). Strengthening the heartbeat: Leading and learning together in schools. San Francisco: Jossey-Bass.

Shapiro, J. P. \& Gross, J. J. (2002). Understanding educational leadership in a time of turbulence. University Council of Educational Administration, Annual Consortium, Pittsburg, P. A. October.

Shapiro, J., \& Stefkovich, J. A. (2005). Ethical leadership and decision making in education: Applying theoretical perspectives to complex dilemmas. Mahwah, NJ: Lawrence Erlbaum Associates, Inc.

Shakeel, F., Kruyen, P., \& Van Thiel, S. (2018, November). Development of the broader ethical leadership scale. Paper presented at the Netherlands Institute of Governance conference, University of Leiden, The Hague, The Netherlands. [Google Scholar]

Sikua, D. D. (2002). The decentralisation of education in a developing country: A case of community high schools in the Solomon Islands. Unpublished PHD thesis, University of Waikato, Hamilton, New Zealand. 
Spillane, J. P., Halverson, R. \& Diamond, J. B. (2004), "Towards a theory of leadership practice: a distributed perspective", Journal of Curriculum Studies, Vol. 36 No.1, pp.3-34.

Starratt, R. J. (1991). Building an ethical school. Educational Administration Quarterly, 27(2),185-196.

Sunley R., and Locke R. (2012). Educational Professionals' Values: Voices from Secondary Schools in England. Educational Research 54(3) pp. 285-307.

Tabachnick, B. G. and Fidell, L. S. (2012). Using Multivariate Statistics. 6h Edition, Person Education, Boston.

Trevino, L. K., Hartman, L. P., \& (2000). Moral person and moral manager: How executives develop a reputation for ethical leadership. California Management Review, 42, 128-142.

Trevino, L. K., Brown, M. \& Hartman, L. P. (2003). A Qualitative Investigation of Perceived Executive Ethical Leadership: Perceptions from Inside and Outside the Executive Suit. Human Relations. Volume 56(1): 5-37.

Tschannen-Moran, M., Uline, C., Woolfolk Hoy, A. and Mackley, T. (2000). Creating smarter schools through collaboration', Journal of Educational Administration, Vol. 38.

Ung Hee, L., Hye Kyoung, K., \& Young Hyung, K. (2013). Determinants of Organizational Citizenship Behavior and Its Outcomes. Global Business $\mathcal{E}$ Management Research, 5(1), 54-65.

Weissbourd, R. (2003). Moral teachers, moral students. Educational Leadership, 60(6), 6-11.

Whitaker, T. T. (2003). What great principals do differently? Larchmont, NY: Eye on Education. 
Author(s) will retain the copyright of their published articles agreeing that a Creative Commons Attribution 4.0 International License (CC BY 4.0) terms will be applied to their work. Under the terms of this license, no permission is required from the author(s) or publisher for members of the community to copy, distribute, transmit or adapt the article content, providing a proper, prominent and unambiguous attribution to the authors in a manner that makes clear that the materials are being reused under permission of a Creative Commons License. Views, opinions and conclusions expressed in this research article are views, opinions and conclusions of the author(s). Open Access Publishing Group and European Journal of Education Studies shall not be responsible or answerable for any loss, damage or liability caused in relation to/arising out of conflicts of interest, copyright violations and inappropriate or inaccurate use of any kind content related or integrated into the research work. All the published works are meeting the Open Access Publishing requirements and can be freely accessed, shared, modified, distributed and used in educational, commercial and non-commercial purposes under a Creative Commons Attribution 4.0 International License (CC BY 4.0). 